\title{
Kvalita vody pražských potoků. Část 2: přítoky do rybníka Šeberák a přehradní nádrže Hostivař
}

\section{LADISLAV HAVEL, BLANKA DESORTOVÁ, JAN ŠŤASTNÝ}

Klíčová slova: potoky - kvalita vody - živiny - fytoplankton - zooplankton

\section{SOUHRN}

Možnost rekreačního využití některých (nejen) pražských nádrží je omezena především kvalitou přitékající vody. Článek navazuje na předchozí část [1] a shrnuje výsledky sledování kvality vody v roce 2018 ve vybraných profilech prítoků do rybníka Šeberák (Vestecký a Kunratický potok) a do přehradní nádrže Hostivař (Botič s Pitkovickým potokem). Sledování bylo zaměřeno na obsah hlavních živin v prítocích (fosfor, dusík), koncentraci chlorofylu-a a kvalitativní složení fytoplanktonu a zooplanktonu v nádržích v povodí. Značné množství živin $v$ přitoku omezuje ve svých důsledcích predevším rekreační využití rybníka Šeberák (hlavně prítokem z Vesteckého potoka). V letech 2017-2018 zde byl po většinu rekreační sezony vyhlášen zákaz koupání, především pro nadměrný výskyt sinic. Botič do přehradní nádrže Hostivař přináší sice nižší, ale také značné množství živin (zhoršená kvalita vody pro koupání byla v letech 2017-2018 po většinu rekreační sezony). Milíčovský potok, který ústí do přehradní nádrže Hostivař v její horní části, je hlavním zdrojem inokula fytoplanktonu.

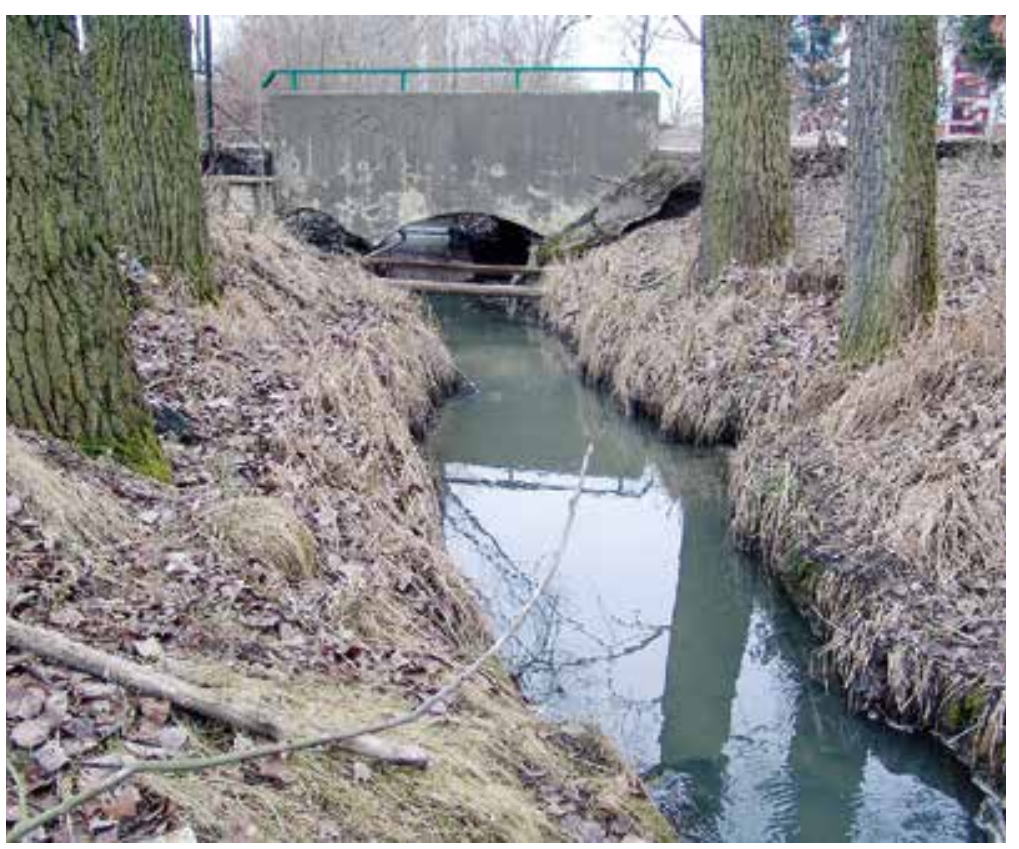

Obr. 1. Vestecký potok, prítok do rybníka Šeberák

Fig. 1. Vestecký stream, inflow to the Šeberák pond

\section{ÚVOD}

V průběhu roku 2018 byla v období březen až listopad sledována kvalita vody na vybraných profilech hlavních př́tokư do prírodních koupališt v jihovýchodní části Prahy: rybník Šeberák (Vestecký a Kunratický potok) a přehradní nádrž Hostivař (Botič, Pitkovický potok). Zatímco prítoky do rybníka Šeberák pramení na území Prahy (nebo těsně za jeho hranicemi), hlavní přítok do přehradní nádrže Hostivař (Botič spolu s Pitkovickým potokem) protéká většinou územím Středočeského kraje.

Rybník Šeberák byl vybudován na Kunratickém potoce; první zmínka o něm je z roku 1602. Zaujímá plochu cca 10 ha (objem vody cca 170 tis. m³). V roce 1933 na něm bylo zrízeno koupaliště. V současné době je jeho účel rekreační, slouží jako zdroj vody pro závlahy a zároveň je významným krajinným prvkem [2]. Na konci roku 2018 byl vypuštěn a v roce 2019 bude odbahněn a revitalizován. Má dva hlavní prítoky: z jižní strany Vestecký potok (obr. 1), z východní Kunratický potok (obr. 2).

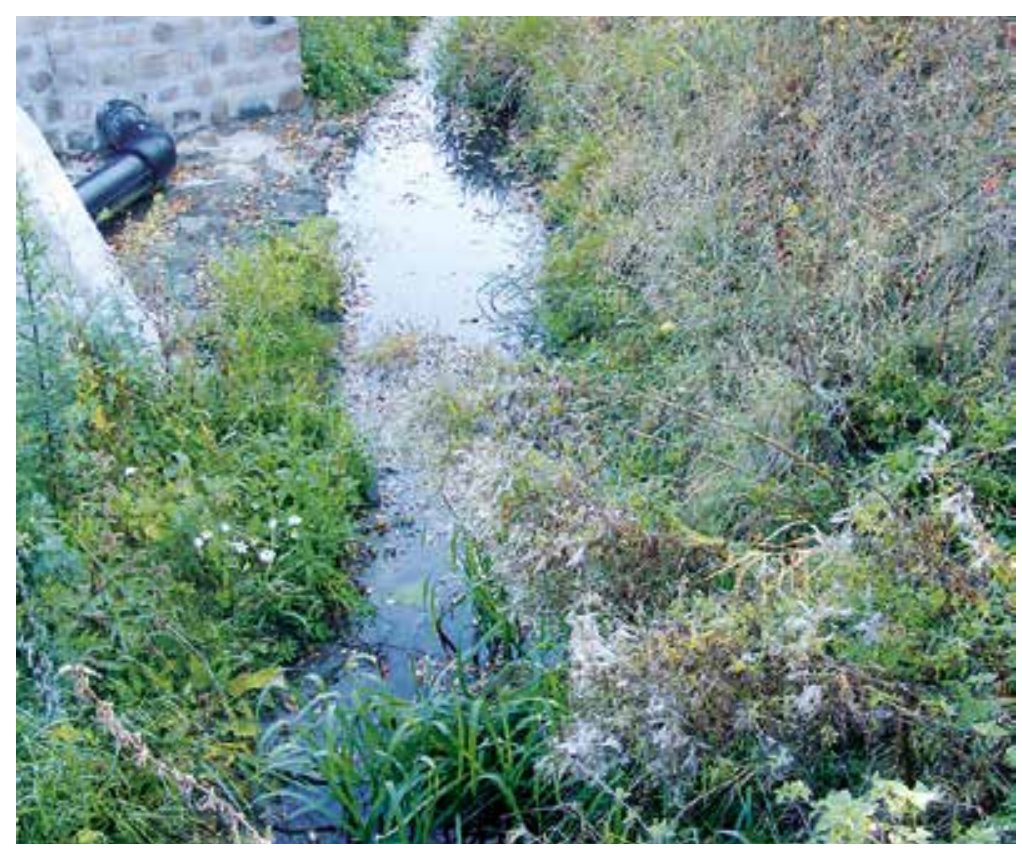

Obr. 2. Kunratický potok, prítok do rybníka Šeberák

Fig. 2. Kunratický stream, inflow to the Šeberák pond 


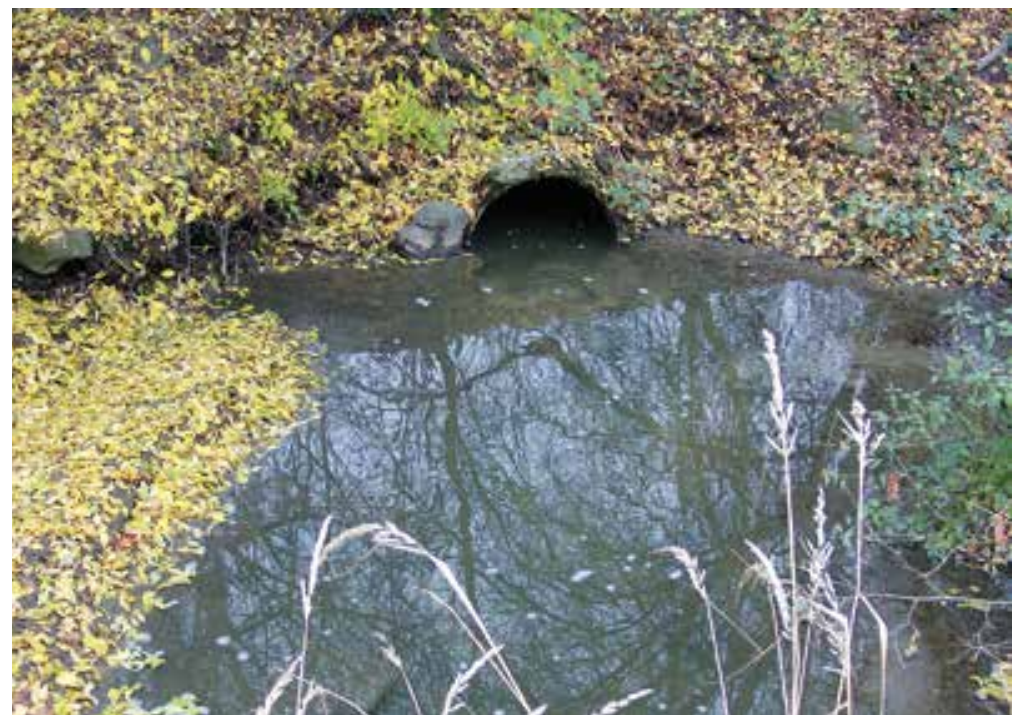

Obr. 3. Olšanský potok, př́tok do Vesteckého potoka

Fig. 3. Olšanský stream, inflow to the Vestecký stream

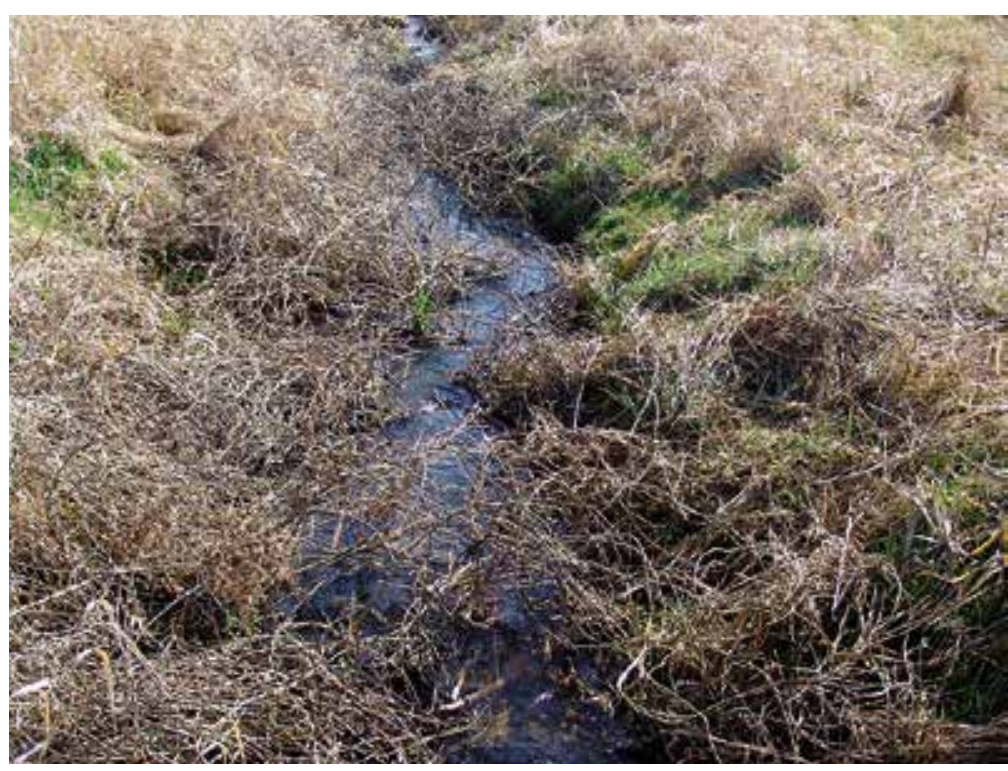

Obr. 4. Hrnčírský rybník, odtok

Fig. 4. Hrnčiřský pond, outflow

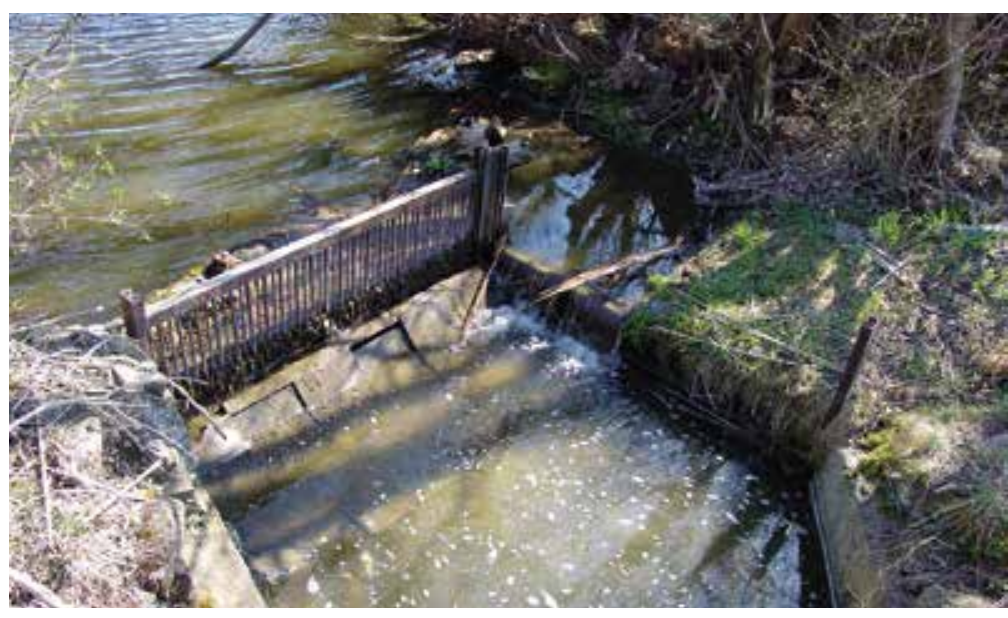

Obr. 5. Rybník Brůdek, odtok

Fig. 5. Brůdek pond, outflow

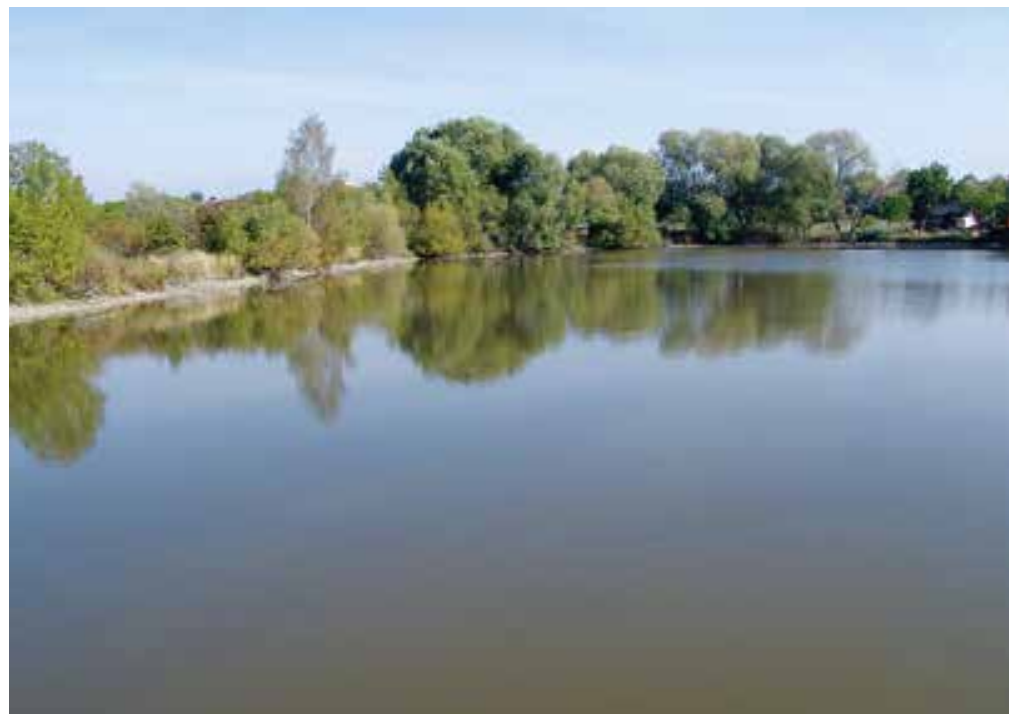

Obr. 6. Šeberovský rybník

Fig. 6. Šeberovský pond

Vestecký potok (délka toku cca 2,8 km) pramení v oblasti Vestce. Na horním toku má několik drobných prítoků, ale jeho hlavním (a v roce 2018 většinou vodnějším) prrítokem je pravostranný Olšanský potok. Olšanský potok (délka toku cca 3,5 km) pramení dvěma větvemi (Olšanský a Olšanský západní), také v oblasti Vestce, $v$ ř. km 0,5 protéká Olšanským rybníkem (v roce 2018 vypuštěný a byly odtěženy sedimenty); odtud teče potrubím pod jahodovými poli v Kunraticích a do Vesteckého potoka vtéká v jeho ř. km 0,6, blízko ústí do Šeberáku [3] (obr.3).

Kunratický potok (celková délka toku cca 13,3 km; z toho pred ústím do rybníka Šeberák cca 2,5km) pramení v oblasti Šeberova [2]; na svém horním toku zásobuje Hrnčiŕský rybník (voda z něj v roce 2018 odtékala dál pouze v jarním období - obr. 4). Poté před vtokem do rybníka Šeberák na ř. km 11 protéká soustavou menších rybníků (Brůdek - obr. 5, odtok; Šeberovský - obr. 6; Nový - po většinu roku 2018 vypuštěný, odtěžovány sedimenty - obr. 7). Z pravé strany se k němu za dostatku vody připojují drobné př́toky z rybníka Jordánek (obr. 8) a z nově rekonstruovaného rybníka Kovářský (obr. 9). Po odtoku z rybníka Šeberák se Kunratický potok po průtoku Kunratickým lesem a dalšími menšími rybníky vlévá v Braníku do Vltavy [3].

Přehradní nádrž Hostivař (Hostivařská přehrada, vodní dílo Hostivař) byla vybudována na potoce Botič v letech 1961-1963. Za normální hladiny je plocha nádrže 39,4 ha; objem vody 1,31 mil. m³. Jejím účelem je rekreace, zmírnění průchodu velkých vod, zároveň je krajinotvorným a ekologickým prvkem a sportovním rybářským revírem. Levý břeh nádrže je využíván jako sportovní areál a největší pražské prírodní koupaliště s kapacitou až 15 tis. osob [2].

Botič (celková délka toku 34,5 km; na území Prahy cca 20 km) pramení jihovýchodně od Prahy ve Středočeském kraji v oblasti mezi obcemi Radějovice a Popovičky, protéká soustavou rybníků v Průhonickém parku [4]. Na ř km 15 ústí do přehradní nádrže Hostivař (obr. 10). Před ústím do přehradní nádrže Hostivař je jeho hlavním prítokem pravostranný Pitkovický potok (obr. 11 a 12); do Botiče se vlévá v jeho ř. km 17,5. Celková délka toku je 15 km (z toho na území Prahy cca 7,5 km), pramení ve Středočeském kraji u obce Strančice. Malým pravostranným př́tokem Botiče je i Dobrá voda (do Botiče ústí v jeho ř. km 17); v odběrových termínech v roce 2018 jím voda neprotékala. Významným př́tokem Botiče před přehradní nádrží Hostivař je levostranný Milíčovský potok. Do Botiče ústí v jeho ř. km 16 a vtéká prímo do horního konce jejího vzdutí (obr. 13). Potok pramení v chráněném území Milíčovský les a v délce $2,6 \mathrm{~km}$ protéká zalesněným územím s převahou listnatých drevin a soustavou rybníků: Milíčovský (obr. 14), Kančík (obr. 15), Homolka (obr. 16), rybářsky obhospodařovaný rybník Vrah - soukromý sportovní rybářský revír (obr. 17), Šáteček (obr. 18). 

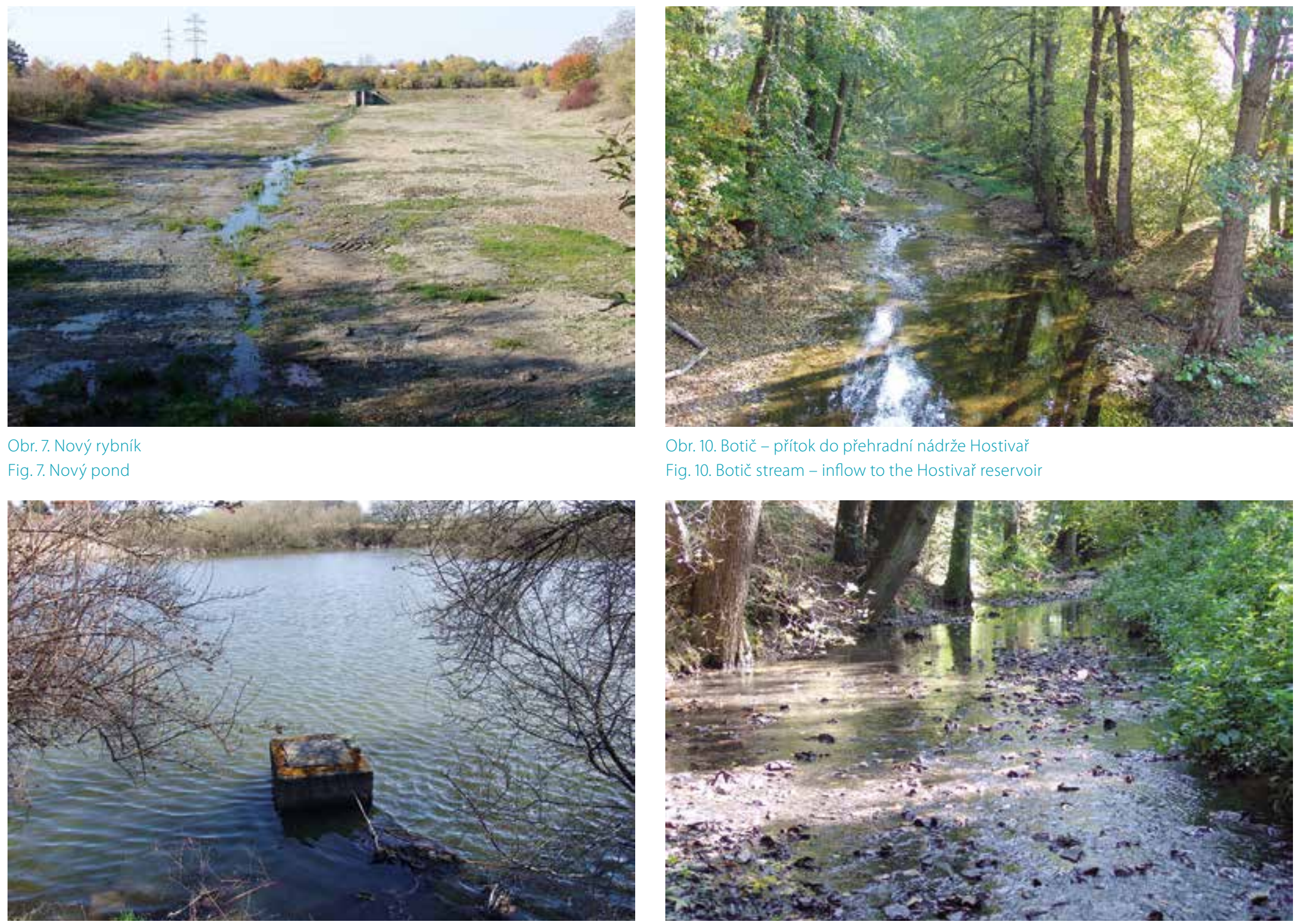

Obr. 10. Botič - prrítok do přehradní nádrže Hostivař

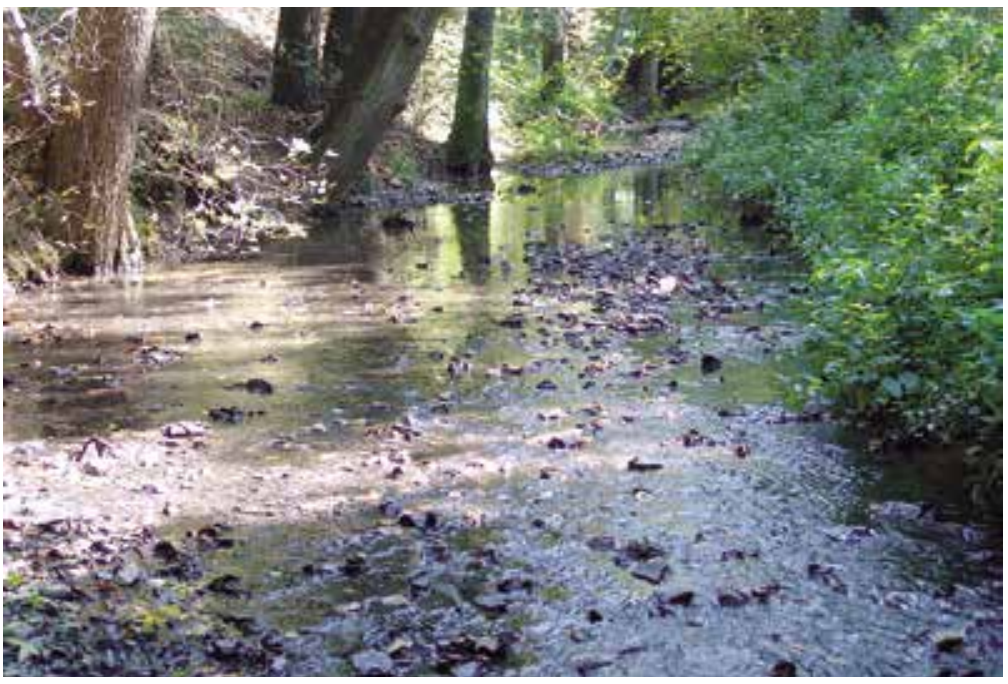

Obr. 8. Rybník Jordánek

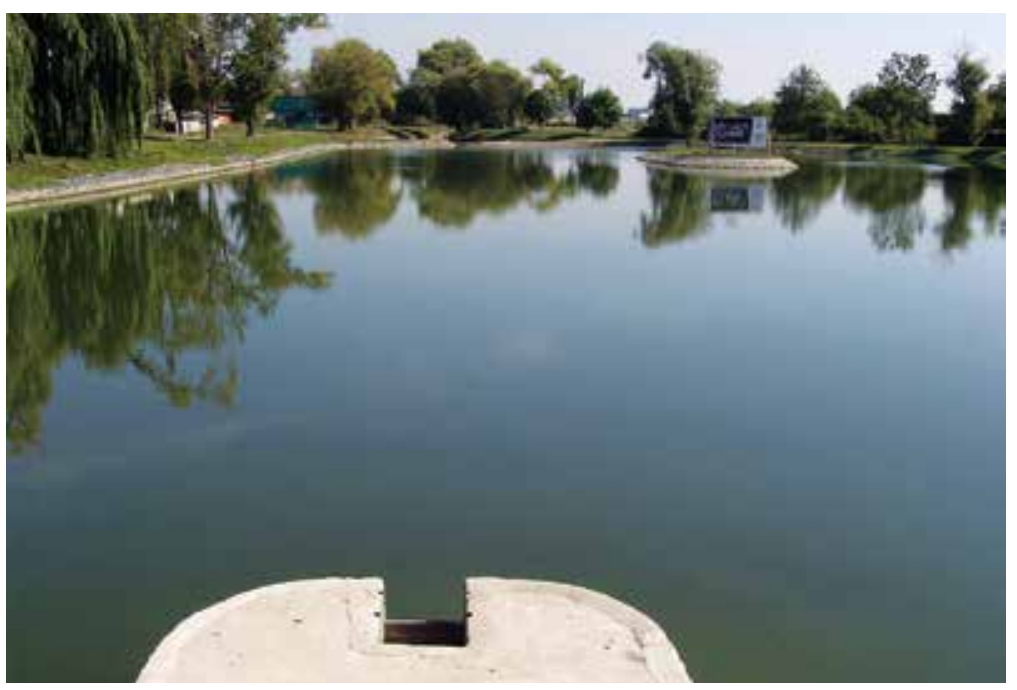

Obr. 11. Pitkovický potok před Botičem

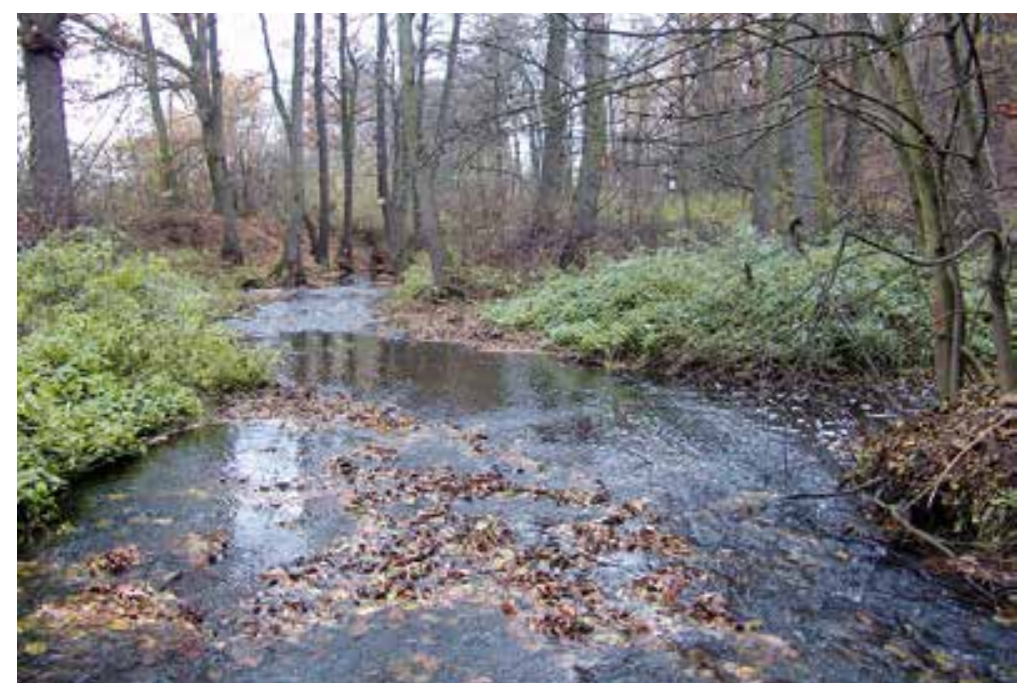

Obr. 9. Rybník Kovářský

Obr. 12 Soutok Pitkovického potoka a Botiče

Fig. 12. Confluence Pitkovický and Botič streams 


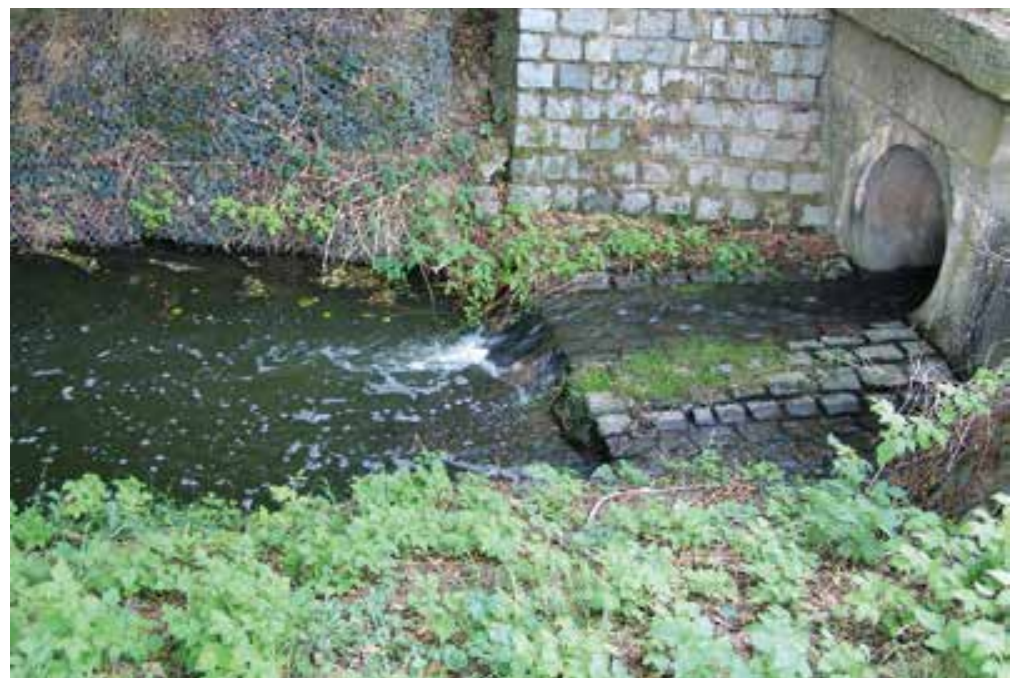

Obr. 13. Miličovský potok; před soutokem s Botičem

Fig. 13. Milíčovský stream; before the confluence with the Botič stream

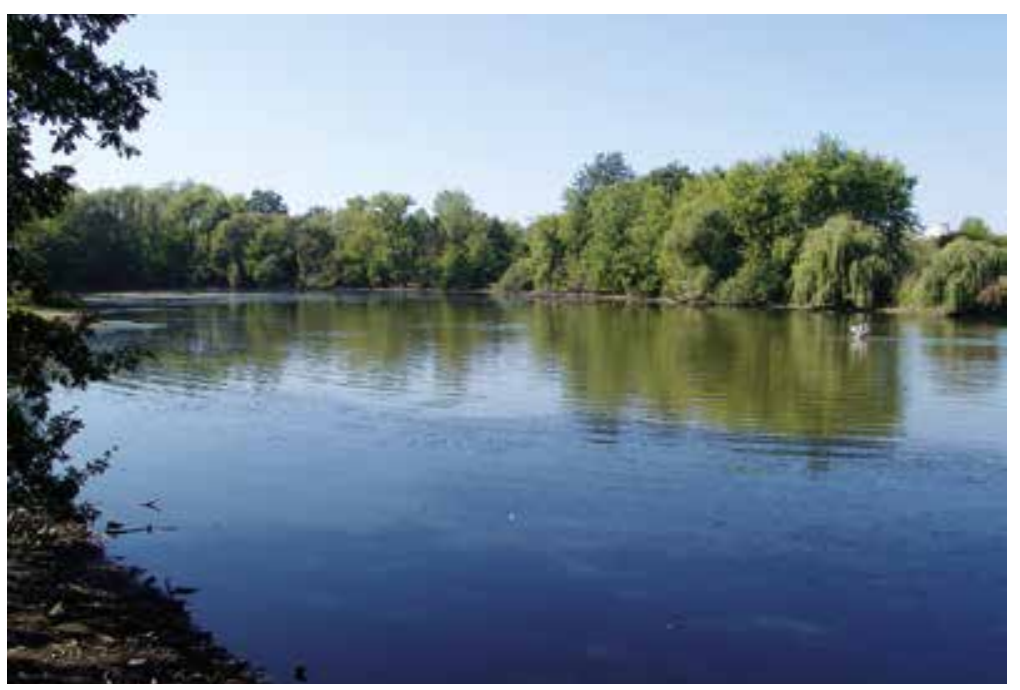

Obr. 14. Milíčovský rybník

Fig. 14. Milíčovský pond

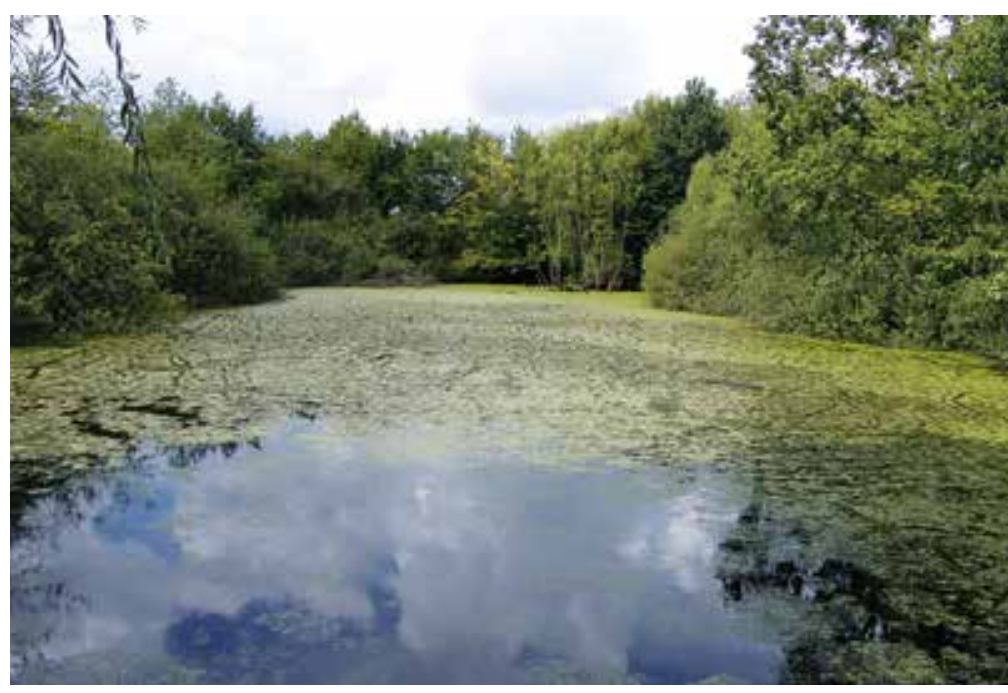

Obr. 15. Rybník Kančík

Fig. 15. Kančík pond

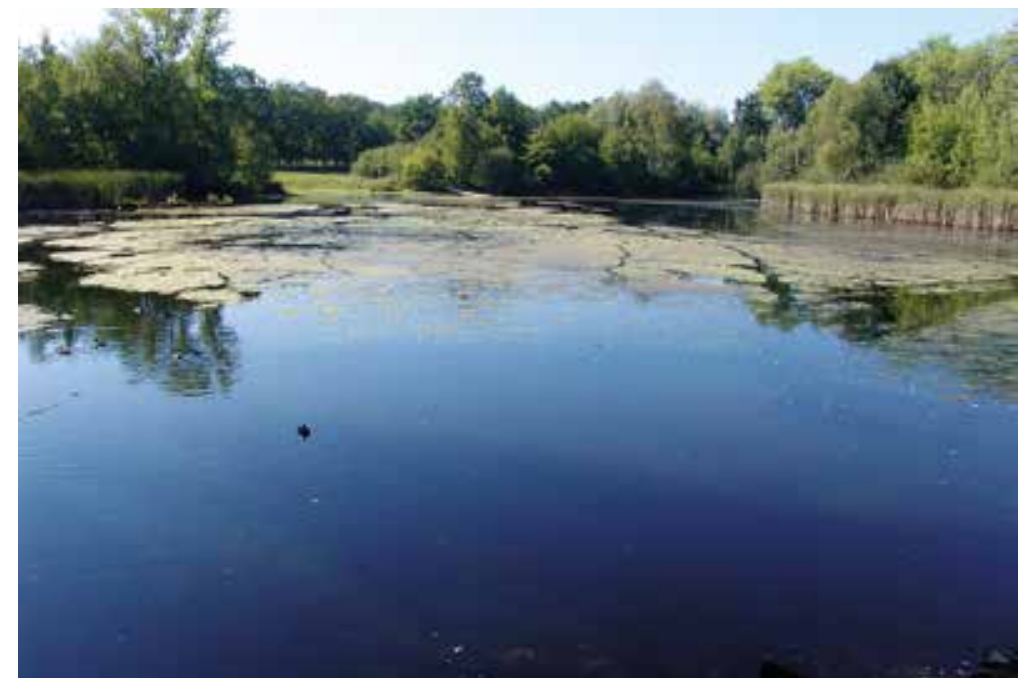

Obr. 16. Rybník Homolka

Fig. 16. Homolka pond

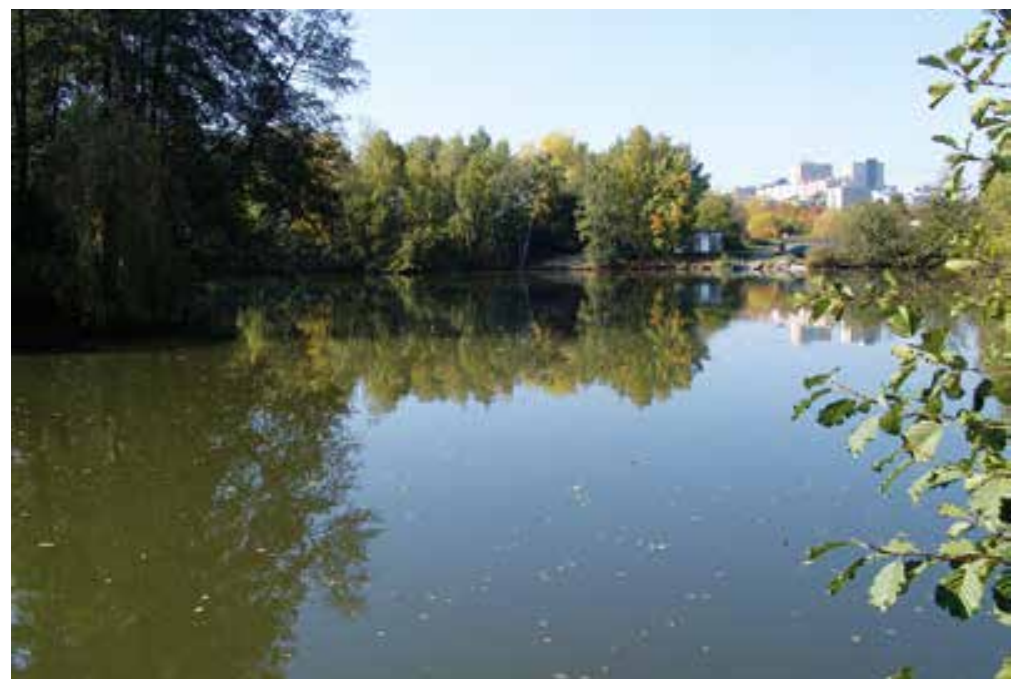

Obr. 17. Rybník Vrah

Fig. 17. Vrah pond

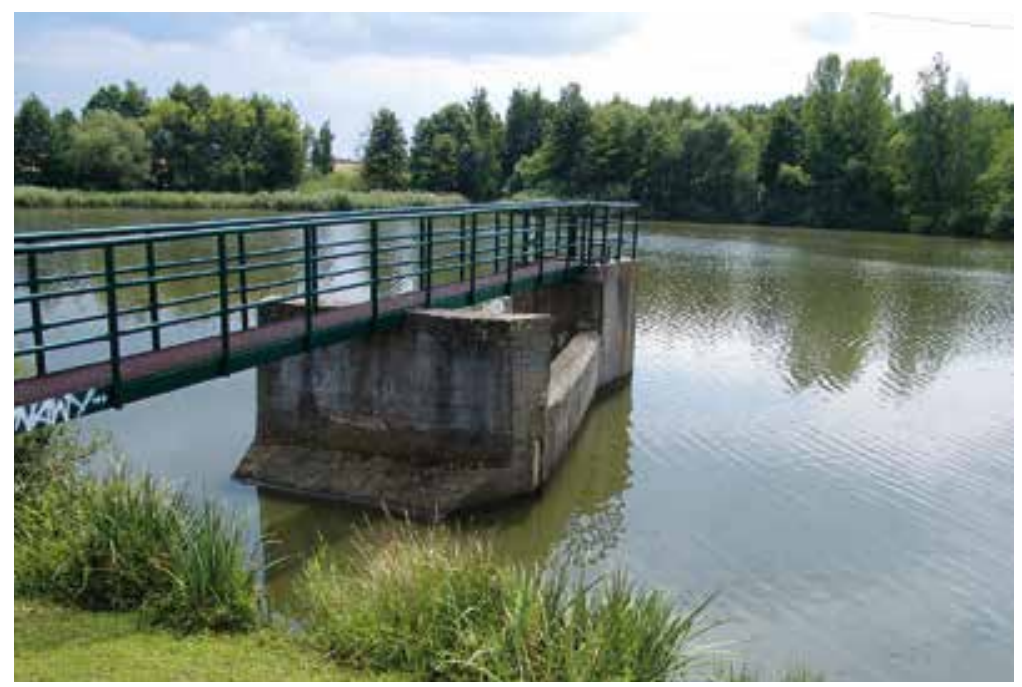

Obr. 18. Rybník Šáteček

Fig. 18. Šáteček pond 


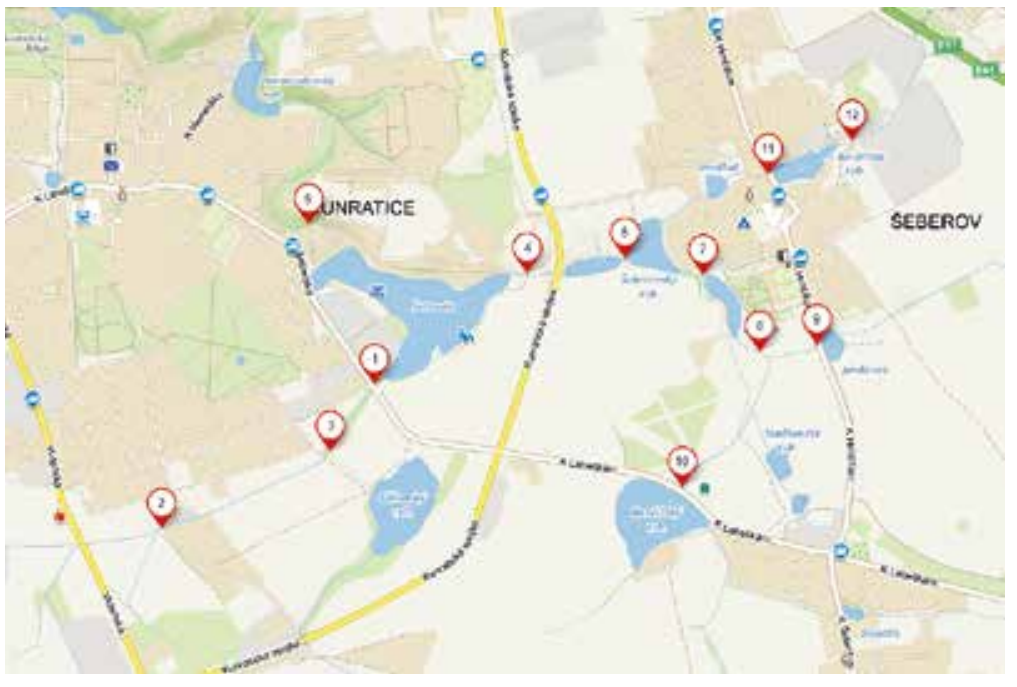

Obr. 19. Odběrová místa v povodí rybníka Šeberák

Fig. 19. Sampling sites in the Šeberák pond catchment area

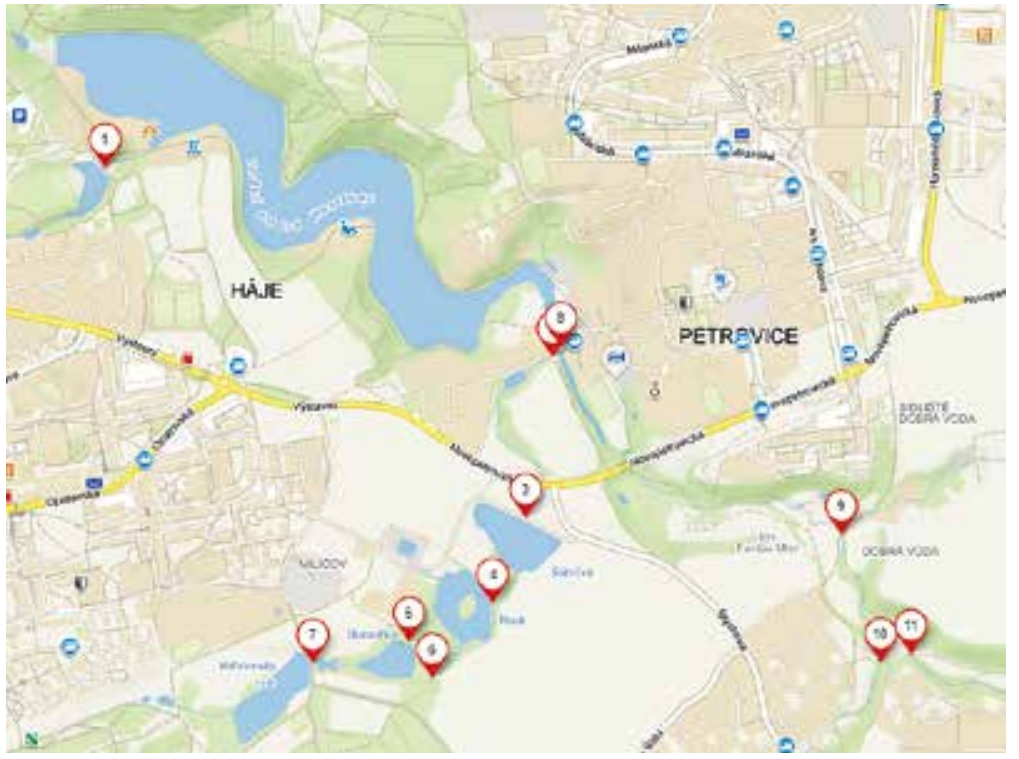

Obr. 20. Odběrová místa v povodí přehradní nádrže Hostivař

Fig. 20. Sampling sites in the Hostivarr reservoir catchment area

Přímo do přehradní nádrže Hostivař z levé strany ústí také Hájecký potok, který odvodňuje retenční nádrže R1-R3 (v roce 2018 trvale bez odtoku). Pod přehradní nádrží Hostivař má Botič charakter přirozeného toku, protéká přírodní památkou Meandry Botiče [2]. Dále teče většinou regulovaným korytem jihovýchodní částí Prahy a jako pravostranný prítok se vlévá pod Vyšehradem do Vltavy [3].

\section{SLEDOVANÉ LOKALITY, METODIKA ODBĚRŮ A ANALÝZ VZORKŮ}

Vzorky pro sledování kvality vody prítoků do obou prírodních koupališt (Šeberák, přehradní nádrž Hostivař) byly v roce 2018 odebírány 1× měsíčně $\checkmark$ období březen až listopad. Seznam odběrových míst je uveden v tabulce 1, jejich poloha je znázorněna na mapách na obr. 19 (Šeberák) a obr. 20 (přehradní nádrž Hostivař). Podkladové mapy byly převzaty z portálu Mapy.cz.
Tabulka 1. Seznam odběrových míst

Table 1. List of sampling sites

\section{Rybník Šeberák}

Profil

Číslo lokality

(obr. 19)

\begin{tabular}{ll}
\hline Vestecký potok - př́tok Šeberák & 1 \\
\hline Vestecký potok - horní část & 2 \\
\hline Olšanský potok - přitok Vestecký & 3 \\
\hline Kunratický potok - přitok Šeberák & 4 \\
\hline Rybník Šeberák - odtok & 5 \\
\hline Šeberovský rybník - odtok & 6 \\
\hline Rybník Brůdek - odtok & 7 \\
\hline Rybník Brůdek - přítok & 8 \\
\hline Rybník Jordánek - odtok & 9 \\
\hline Hrnčířský rybník - odtok & 10 \\
\hline Kovářský rybník - odtok & 11 \\
\hline Kovářský rybník - př́tok & 12
\end{tabular}

\section{Přehradní nádrž Hostivař}

Profil

Číslo lokality

(obr. 20)

\begin{tabular}{ll}
\hline RN Hájecký - odtok & 1 \\
\hline Milíčovský potok - přitok do Botiče & 2 \\
\hline Rybník Šáteček - odtok & 3 \\
\hline Rybník Vrah - odtok & 4 \\
\hline Rybník Homolka - odtok L & 5 \\
\hline Rybník Homolka - odtok P & 6 \\
\hline Milíčovský rybník - odtok & 7 \\
\hline Botič - př́tok do přehradní nádrže Hostivař & 8 \\
\hline Botič - pod soutokem s Pitkovickým potokem & 9 \\
\hline Botič - nad soutokem s Pitkovickým potokem & 10 \\
\hline Pitkovický potok - nad soutokem s Botičem & 11
\end{tabular}

Vzorky vody byly odebírány na hlavních přítocích do obou nádržía na odtoku z rybníků v povodí (vždy, pokud existoval). Odběry v terénu doprovázelo in-situ měření fyzikálně-chemických charakteristik kvality vody (teplota, pH, koncentrace rozpuštěného kyslíku, nasycení vody kyslíkem). Laboratorní analýzy vzorků byly zaměřeny na stanovení jednotlivých forem dusíku ( $\mathrm{N}-\mathrm{NH}_{4}, \mathrm{~N}-\mathrm{NO}_{3^{\prime}} \mathrm{N}-\mathrm{NO}_{2^{\prime}}$ $\mathrm{N}$-org., $\mathrm{N}$-celk.) a fosforu ( $\mathrm{P}-\mathrm{PO}_{4^{\prime}} \mathrm{P}$-celk.). Hydrobiologické analýzy vzorků zahrnovaly stanovení koncentrace chlorofylu-a jako měř́tka biomasy fytoplanktonu a kvalitativní složení společenstva fytoplanktonu a zooplanktonu. Odběry vzorků a jejich analýzy v laboratoři VúV TGM, v. v. i., byly prováděny standardními postupy [5-10], popř. podle schválených metodik [11, 12]. 


\section{VÝSLEDKY}

\section{Chemické ukazatele}

\section{RYBNÍK ŠEBERÁK A PŘÍTOKY}

\section{Vestecký potok}

$\mathrm{Na}$ obr. 21 jsou znázorněny průměrné a maximální koncentrace $\mathrm{N}-\mathrm{NH}_{4^{\prime}} \mathrm{N}-\mathrm{NO}_{3^{\prime}}$ $\mathrm{P}_{-} \mathrm{PO}_{4}$ a P-celk. v závěrném profilu levostranného př́toku do rybníka Šeberák (profil je označen jako Šeberák př́tok L). Z obr. 21 je zřejmé, že přísun živin závěrným profilem Vesteckého potoka do tohoto rekreačního rybníka byl v celém sle-

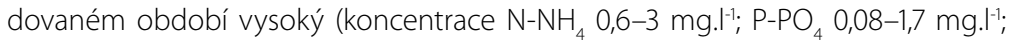
P-celk. 0,2-2 mg.l-1). Vestecký potok byl ve své horní části od července 2018 neprůtočný, ale při odběru 15. 5. 2018 v něm byly zaznamenány nejvyšší koncen-

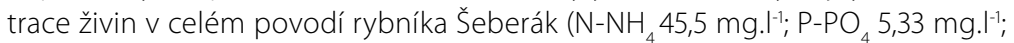
P-celk. 6,26 mg.l-1; el. konduktivita $\left.1390 \mu \mathrm{S} . \mathrm{cm}^{-1}\right)$. Prítok z Olšanského potoka výrazně vodu $v$ závěrném profilu prítoku do Šeberáku ve výsledku "naře-

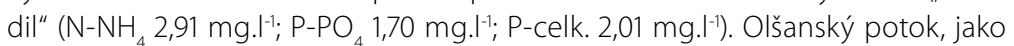
hlavní přitok Vesteckého potoka, přinášel trvale velmi vysoké koncentrace živin $\left(\mathrm{N}-\mathrm{NH}_{4}\right.$ 0,06-2,85 mg. $\mathrm{I}^{-1} ; \mathrm{P}^{-} \mathrm{PO}_{4} 0,16-0,42 \mathrm{mg} . \mathrm{I}^{-1} ; \mathrm{P}$-celk. 0,44-1,9 mg. $\left.{ }^{-1}\right)$.
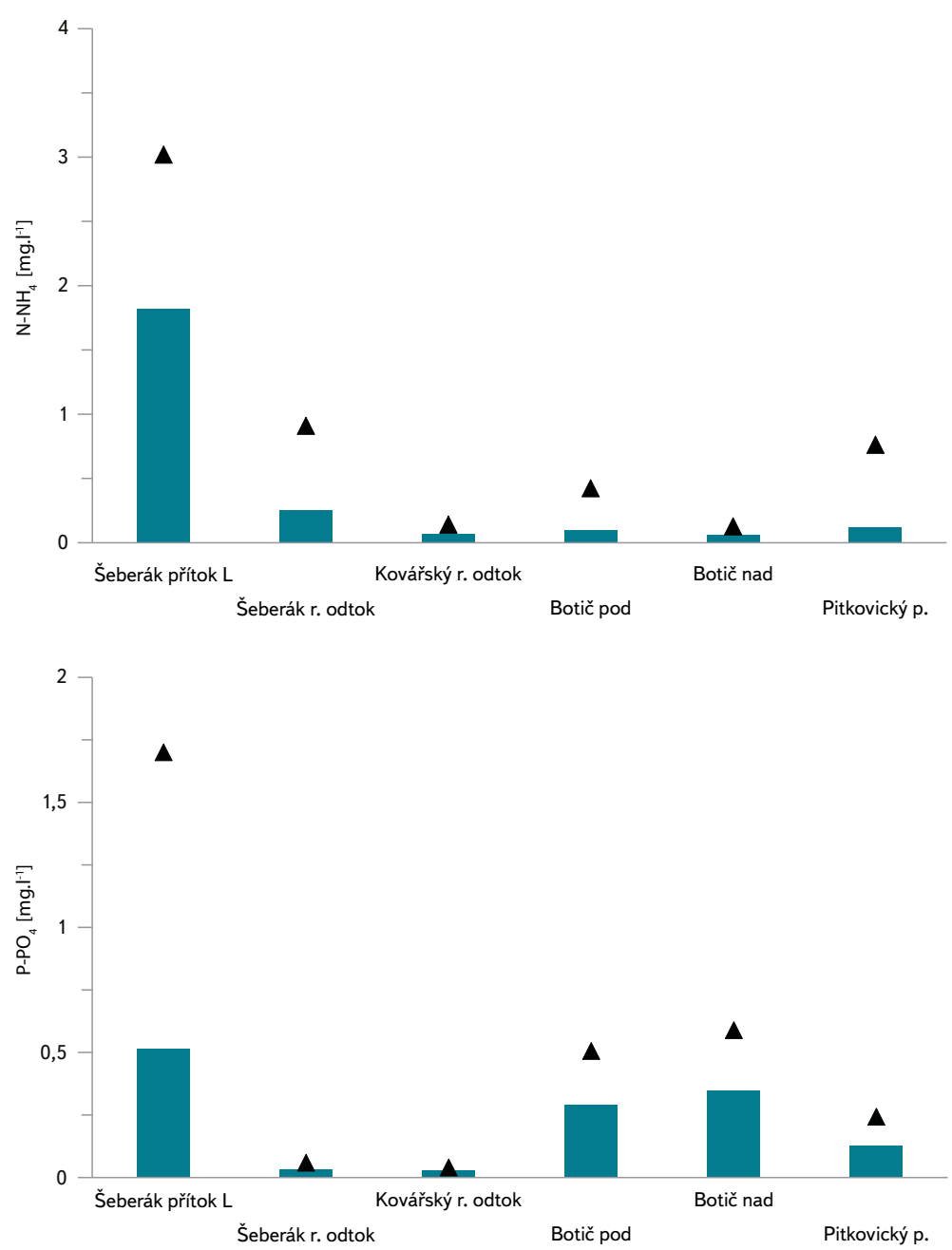

\section{Kunratický potok}

Pravostranný prítok ovlivnil v roce 2018 přísun živin do rybníka Šeberák pouze minimálně (velmi nízký průtok v první polovině roku 2018, nulový průtok v jeho druhé polovině). V první polovině roku 2018 byly v př́toku Kunratického potoka do rybníka Šeberák oproti Vesteckému potoku zaznamenány nižší koncentrace živin ( $\mathrm{N}-\mathrm{NH}_{4}$ 0,04-0,43 mg..$^{-1} ; \mathrm{P}_{-} \mathrm{PO}_{4}<0,025-0,06$ mg..$^{-1}$; P-celk. 0,09-0,25 mg. $\left.\mathrm{I}^{-1}\right)$. Průtokové a kvalitativní poměry Kunratického potoka ovlivňovala především situace v jeho povodí - soustava rybníků (Šeberovský, Brůdek, Jordánek, Kovářský). Koncentrace hlavních živin na odtoku z některých rybníků v povodí jsou na obr. 21 (označeny jako Šeberovský r. odtok; Kovářský r. odtok). Většina těchto rybníků je značně zarybněná.

\section{PŘEHRADNÍ NÁDRŽ HOSTIVAŘ}

Botič a př́ítoky

$\mathrm{Na}$ obr. 21 jsou znázorněny průměrné a maximální koncentrace $\mathrm{N}-\mathrm{NH}_{4^{\prime}} \mathrm{N}^{-\mathrm{NO}_{3^{\prime}}}$ $\mathrm{P}_{-} \mathrm{PO}_{4}$ a $\mathrm{P}$-celk. ve sledovaných profilech Botiče (jako hlavním a trvalém př́toku do přehradní nádrže Hostivař). V roce 2018 byly odebírány vzorky ve třech profilech: Botič před soutokem s Pitkovickým potokem (na obr. 21 označen jako Botič nad); Pitkovický potok pred soutokem s Botičem (na obr. 21 označen jako
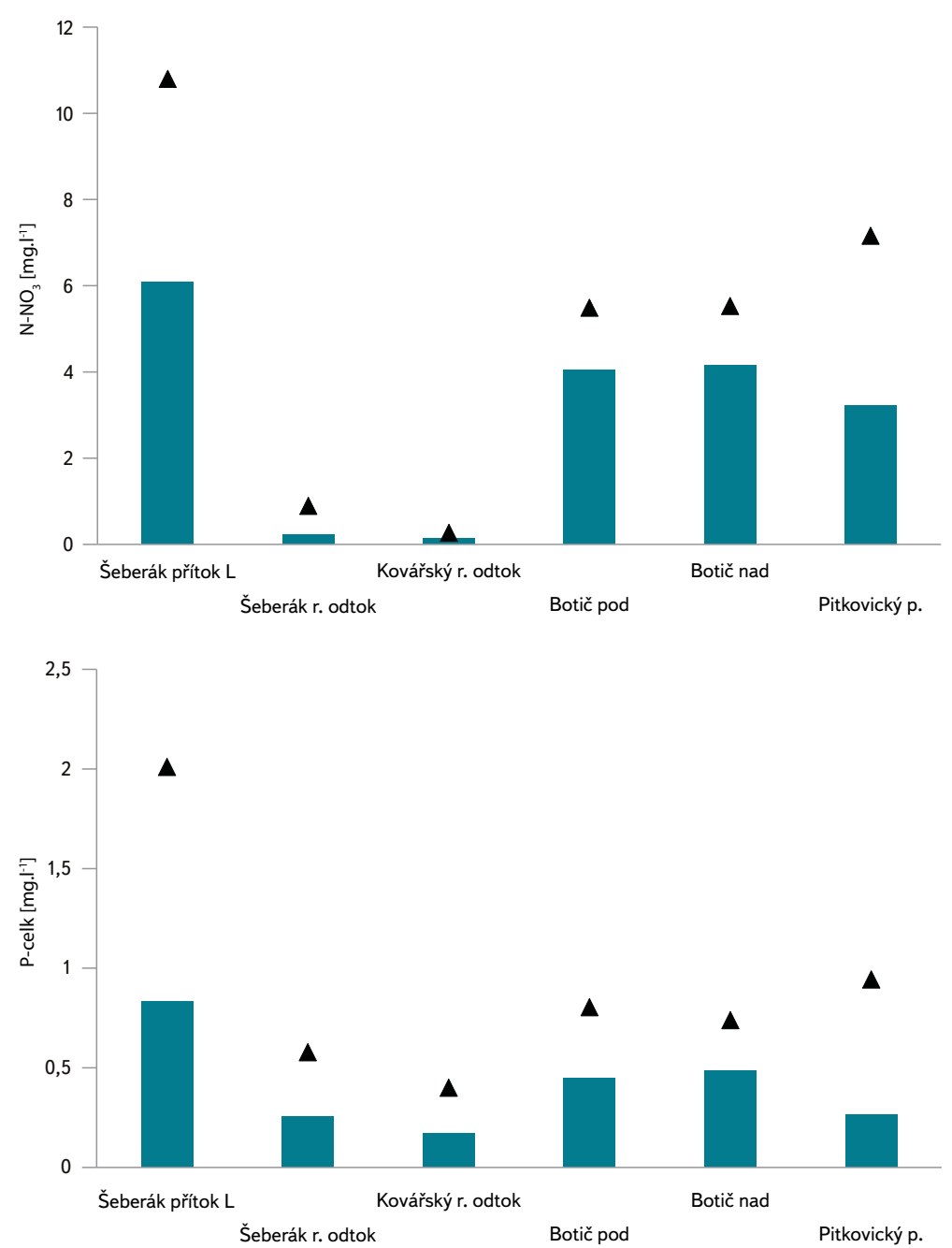
Pitkovický p.); Botič pod soutokem s Pitkovickým potokem a před vtokem do přehradní nádrže Hostivař (na obr. 21 označen jako Botič pod). Z výsledků je zřejmé, že oba potoky jsou pro přehradní nádrž Hostivař značným zdrojem živin (především fosforu). V Botiči před soutokem s Pitkovickým potokem byly v roce 2018 koncentrace $\mathrm{P}_{-} \mathrm{PO}_{4}<0,025-0,6$ mg. ${ }^{\mid-1} ; \mathrm{P}$-celk. 0,16-0,74 mg. I $^{-1}$. V Pitkovickém potoce byly koncentrace živin jen o málo nižší $\left(\mathrm{P}_{-}-\mathrm{PO}_{4}\right.$ 0,03-0,24 mg.|-1-1 $\mathrm{P}$-celk. 0,065-0,94 mg. $\left.\mathrm{I}^{-1}\right)$. Hodnoty těchto ukazatelů v Botiči před vtokem do přehradní nádrže Hostivař většinou (v závislosti na vzájemných průtokových poměrech) př́tok Pitkovického potoka jen mírně snižuje (koncentrace $\mathrm{P}^{-\mathrm{PO}_{4}}<0,025-0,38$ mg. I $^{-1}$; P-celk. 0,16-0,92 mg. $\left.\right|^{-1}-$ obr. 21).

\section{Milíčovský potok}

Množství živin, prìtékající Milíčovským potokem (koncentrace $\mathrm{P}_{-} \mathrm{PO}_{4}<0,025$ mg. $\mathrm{I}^{-1}$; P-celk. 0,07-0,21 mg. $\left.{ }^{-1}\right)$, nemá vzhledem k poměru průtoků na kvalitu vody Botiče zásadní vliv. Hlavním problémem a rizikem pro přehradní nádrž Hostivař a její rekreační využití je (kromě př́sunu živin z povodí Botiče) přítok značného množství inokula fytoplanktonu z rybníků v povodí, kterými potok protéká. Například v rybníku Šáteček (poslední rybník soustavy) dosahovaly koncentrace chlorofylu-a 150-170 $\mu \mathrm{g}$. $^{-1}$. V Miličcovském potoce $v$ př́toku do Botiče těsně pred vzdutím přehradní nádrže Hostivař byla zjištěna koncentrace chlorofylu-a až $100 \mu \mathrm{g} \cdot \mathrm{I}^{-1}$ (obr. 23)
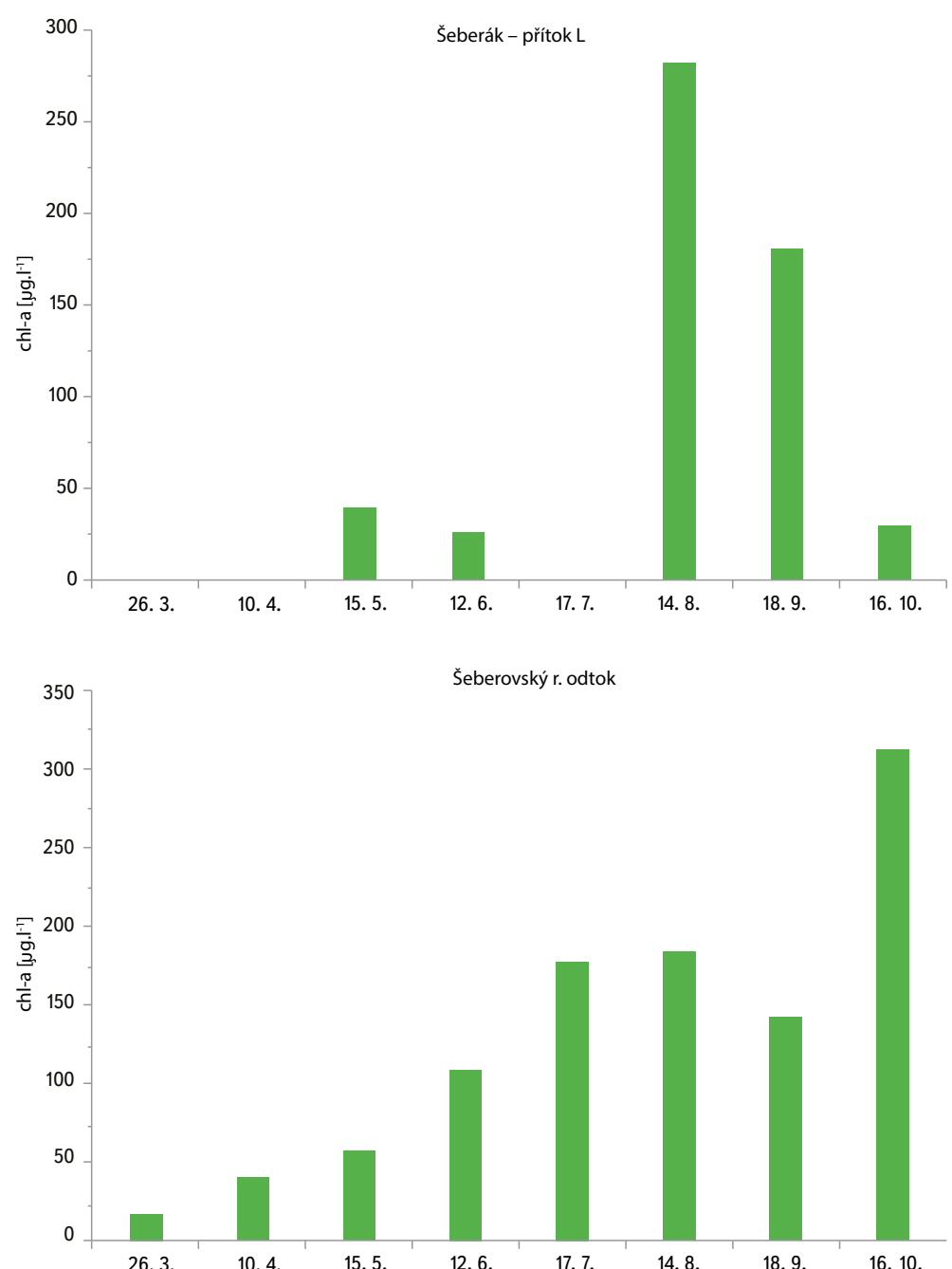

\section{Hydrobiologické ukazatele}

\section{CHLOROFYL-A}

\section{Vestecký a Kunratický potok}

Na obr. 22 jsou graficky znázorněny změny obsahu chlorofylu-a během vegetační sezony (březen-ř́jen) ve vybraných profilech Vesteckého a Kunratického potoka. Oba toky mají z hlediska biomasy fytoplanktonu významný vliv na kvalitu vody v rybníce Šeberák. Ve sledovaném profilu Šeberák - prítok L (Vestecký potok) byly v srpnu a září 2018 zjištěny vysoké hodnoty koncentrace chlorofylu-a 262,7 $\mu \mathrm{g} . \mathrm{I}^{-1}$ a 168,2 $\mu \mathrm{g} . \mathrm{I}^{-1}$. Důsledkem přísunu vysokého množství živin a inokula ras dochází v rybníce Šeberák k silnému rozvoji fytoplanktonu. V období květen až zárí se hodnoty chlorofylu-a v hladinové vrstvě rybníka Šeberák pohybovaly v rozmezí 142,4-278,5 $\mu \mathrm{g}$. $^{-1}$ (obr. 22). Vysoká biomasa fytoplanktonu způsobila snížení průhlednosti vody až na 0,15 m. V rybníce došlo k vývoji mohutného vodního květu, který tvořila kokální sinice Microcystis aeruginosa doprovázená ojedinělými koloniemi druhu Microcystis wesenbergii.

Podobně také ve sledovaných profilech na Kunratickém potoce, který protéká několika rybníky, byly v průběhu vegetační sezony zjištěny nadměrné koncentrace chlorofylu-a (obr. 22). Dokladem je průběh změn koncentrace chlorofylu-a v profilu Šeberovský rybník - odtok. V letních měsících se koncentrace
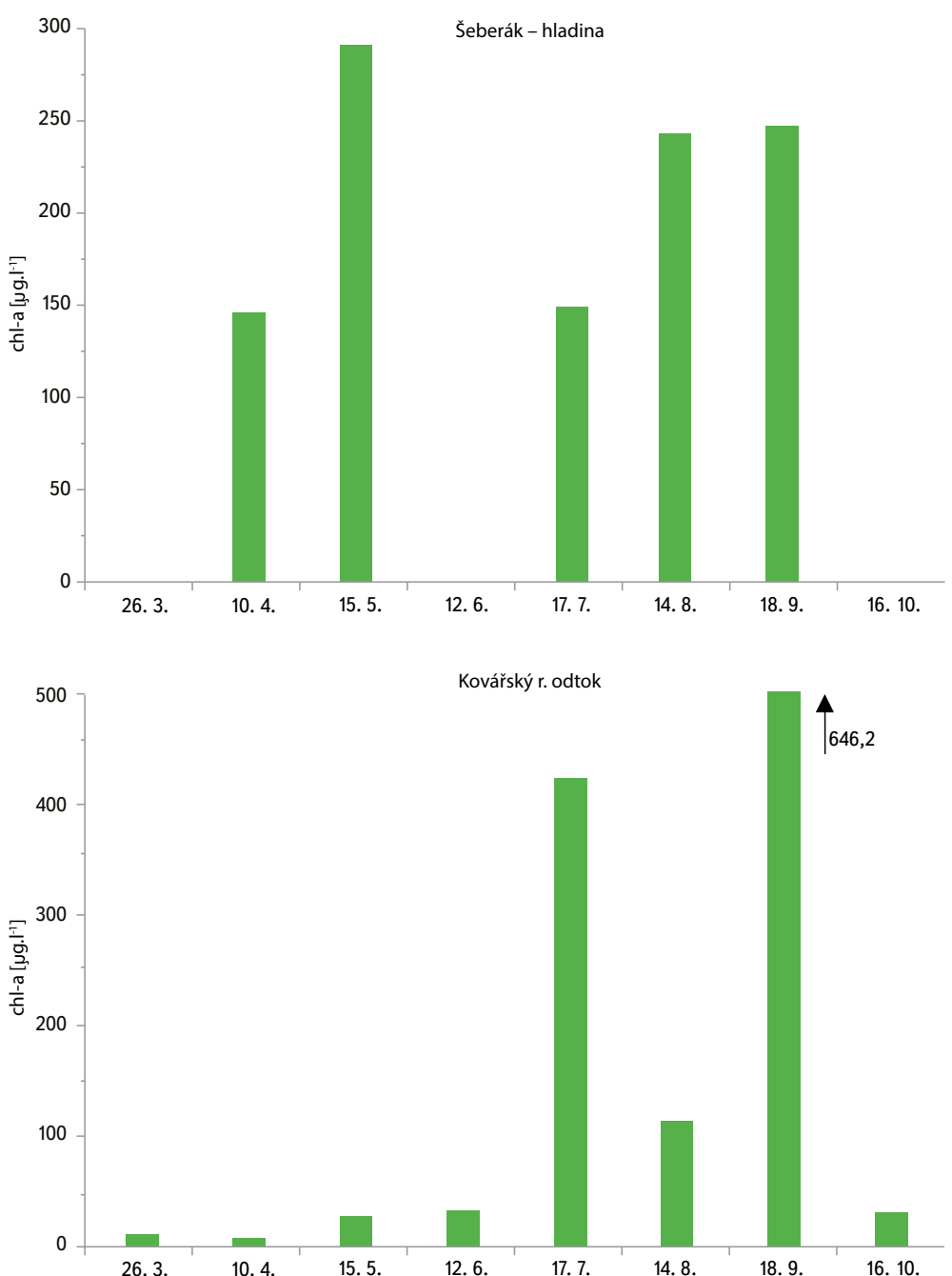

Obr. 22. Sezonní změny koncentrace chlorofylu-a ve sledovaných profilech v povodí Šeberáku

Fig. 22. Seasonal changes of chlorophyll-a concentration in the studied profiles of the Šeberák catchment area 

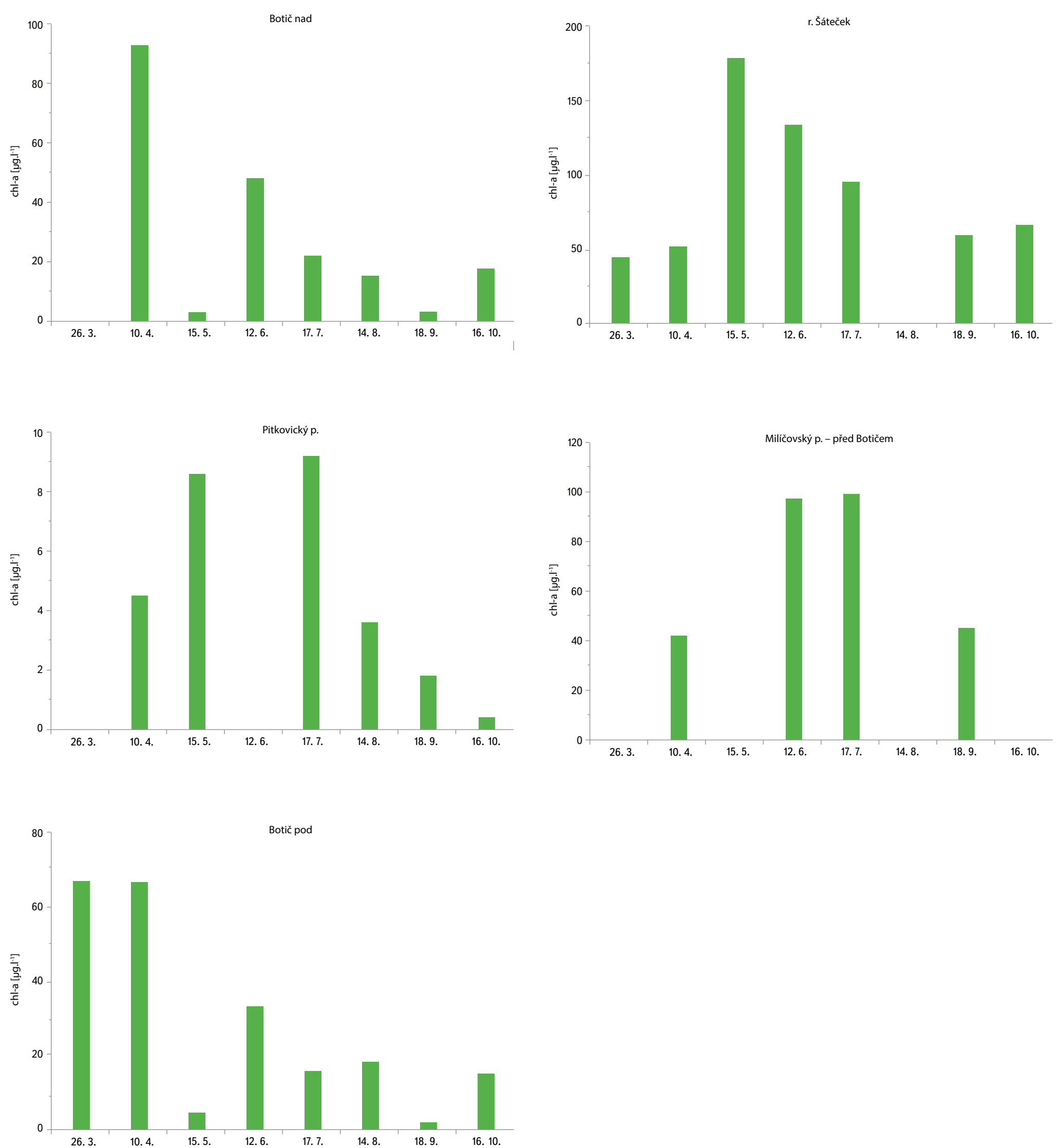

Obr. 23. Sezonní změny koncentrace chlorofylu-a ve sledovaných profilech v povodí přehradní nádrže Hostivař

Fig. 23. Seasonal changes of chlorophyll-a concentration in the studied profiles of the Hostivař reservoir catchment area 
chlorofylu-a pohybovaly v rozmezí 108,4-183,3 ㅆ..-1, maximální hodnota kon-

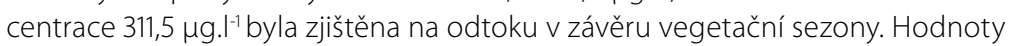
průhlednosti vody měřené $v$ rybníce Šeberovský byly $\vee$ rozmezí 0,10-0,25 m. V období červen-listopad se $v$ rybníce vyskytoval vodní květ, který tvořila sinice Microcystis aeruginosa. Nadměrně vysoké koncentrace chlorofylu-a byly zjištěny i na odtoku z rybníka Kovářský. První polovina vegetační sezony, až do června, byla charakteristická prítomností nízké biomasy fytoplanktonu, následně došlo k jejímu enormnímu rozvoji. Koncentrace chlorofylu-a dosáhla

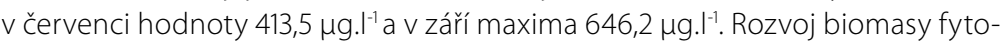
planktonu vedl v rybníce ke vzniku vegetačního zákalu a poklesu průhlednosti vody. Vegetační zákal byl tvořen v první polovině léta zejména zástupci ze skupiny zelených řas (Chlorophyceae). Hodnoty průhlednosti vody měřené v rybníce se $v$ této době pohybovaly kolem 0,15 m. V závěru vegetační sezony byla na odtoku z nádrže zjištěna nejvyšší hodnota koncentrace chlorofylu-a (646,2 $\left.\mu \mathrm{g} . .^{-1}\right)$ ze všech sledovaných lokalit. Ve fytoplanktonu se v tomto prípadě vyskytovala pouze obrněnka Ceratium hirundinella, zástupce skupiny Dinophyceae.

\section{Botič a Milíčovský potok}

Změny obsahu chlorofylu-a během vegetační sezony jsou pro vybrané profily Botiče a Milíčovského potoka znázorněny na obr. 23. Množství fytoplanktonu $\checkmark$ potoce Botič bylo sledováno ve dvou profilech: nad soutokem s Pitkovickým potokem (Botič nad) a na vtoku do přehradní nádrže Hostivař (Botič pod). $\checkmark$ místě pod soutokem byly hodnoty chlorofylu-a $\vee$ Botiči mírně nižší než $\checkmark$ profilu nad soutokem s Pitkovickým potokem, který měl díky svému nízkému obsahu fytoplanktonu $v$ průběhu vegetační sezony (maximální zjištěná hodnota chlorofylu-a 9,2 $\mu \mathrm{g} . .^{-1}$ ) ředící efekt pro vodu v Botiči. Přesto zejména $\checkmark$ jarním období (březen-duben) byla biomasa fytoplanktonu $\vee$ Botiči na vtoku do přehradní nádrže Hostivař poměrně vysoká (koncentrace chlorofylu-a cca $\left.67 \mu \mathrm{g} . \mathrm{l}^{-1}\right)$. Významné množství fytoplanktonu se do přehradní nádrže Hostivař dostává také Milíčovským potokem (obr. 23), který protéká soustavou rybníků v Miličovském lese. Vodnost Milíčovského potoka je závislá na odtoku z rybníka Šáteček, ze kterého ve sledovaném období vzhledem k poklesu hladiny vody (důsledek nedostatku srážek a sucha) v některých termínech odběru vzorků voda neodtékala. Nicméně v červnu a červenci byla ve sledovaném

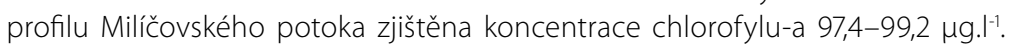
Prímo v rybníce Šáteček se v květnu až červenci hodnoty chlorofylu-a pohybo-

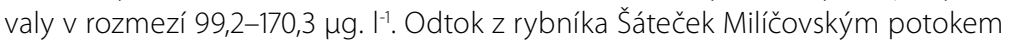
je významným zdrojem inokula fytoplanktonu pro blízkou přehradní nádrž Hostivařr.

\section{Fytoplankton}

Druhové složení fytoplanktonu sledovaných profilů bylo, s výjimkou potoků Botiče a Pitkovického, ovlivněno skladbou fytoplanktonu rybníků. $\checkmark$ jarním období se vyskytovali predevším zástupci centrických rozsivek (Cyclostephanos invisitatus, Aulacoseira granulata, Melosira varians, Stephanodiscus spp.) a druhy rodů Cryptomonas (Cryptophyceae), Chrysococcus (Chrysophyceae) a Trachelomonas (Euglenophyta). V letním a podzimním období bylo složení společenstva fytoplanktonu velmi pestré s přitomností řady taxonů, zejména zelených řas (Chlorophyceae). Ze skupiny kokálních zelených řas se vyskytovaly druhy rodů Actinastrum, Ankyra, Coelastrum, Crucigenia, Desmodesmus, Dictyosphaerium, Monoraphidium, Oocystis, Pediastrum, Scenedesmus, Tetraedron. Bičíkovci byli zastoupeni druhy rodů Euglena, Chlamydomonas, Pandorina, Phacotus, Pteromonas. Vodní květ, tvořený kokální sinicí Microcystis aeruginosa, byl v průběhu sledování zaznamenán na odtoku z rybníků Šeberák a Šeberovský. Výskyt ojedinělých vloček vláknité sinice Aphanizomenon flos-aquae byl zjištěn ve fytoplanktonu rybníků Šeberák a Kovářský.

\section{Zooplankton}

Kvalitativní složení společenstva zooplanktonu bylo $v$ roce 2018 orientačně sledováno v rybnících v povodí Kunratického potoka (Šeberovský, Brůdek, Kovářský) a Botiče (Homolka, Vrah, Šáteček) v červenci a říjnu. Oproti rybníkům a nádržím v povodí Motolského a Litovického potoka v západní části Prahy [1] bylo složení zooplanktonu v těchto rybnících velmi uniformní, indikuje vysokou rybí obsádku. Ve všech sledovaných rybnících v obou termínech odběrů v jeho složení dominovali zástupci skupin:

- Rotifera: ve všech rybnících dominovali zástupci rodů Keratella (především K. quadrata, K. cochlearis), Brachionus (B. calyciflorus, B. urceolaris), Asplanchna priodonta.

- Copepoda (především malé druhy): Microcyclops bicolor, Cyclops strenuus, Paracyclops sp., Thermocyclops sp.). Méně - v letním období - se v některých rybnících hojněji vyskytoval Eudiaptomus gracilis (Šeberovský, Kovářský). Ve všech lokalitách se trvale vyskytovala kopepoditová a naupliová stadia.

- Cladocera: ve všech sledovaných rybnících trvale dominovala Bosmina longirostris; s mnohem nižší abundancí se vyskytovala Ceriodaphnia sp. Perloočka Daphnia galeata byla v nízkých počtech prítomna v rybnících Brůdek, Kovářský, Šáteček a Vrah.

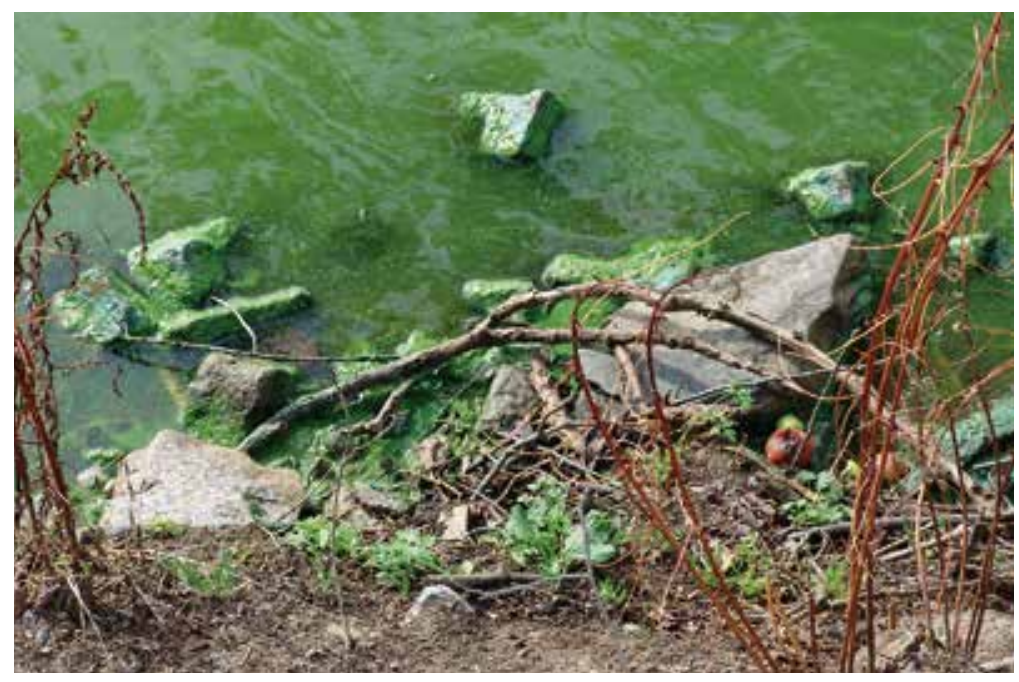

Obr. 24. Vodní květ sinic - rybník Šeberák

Fig. 24. Cyanobacteria water bloom - Šeberák pond

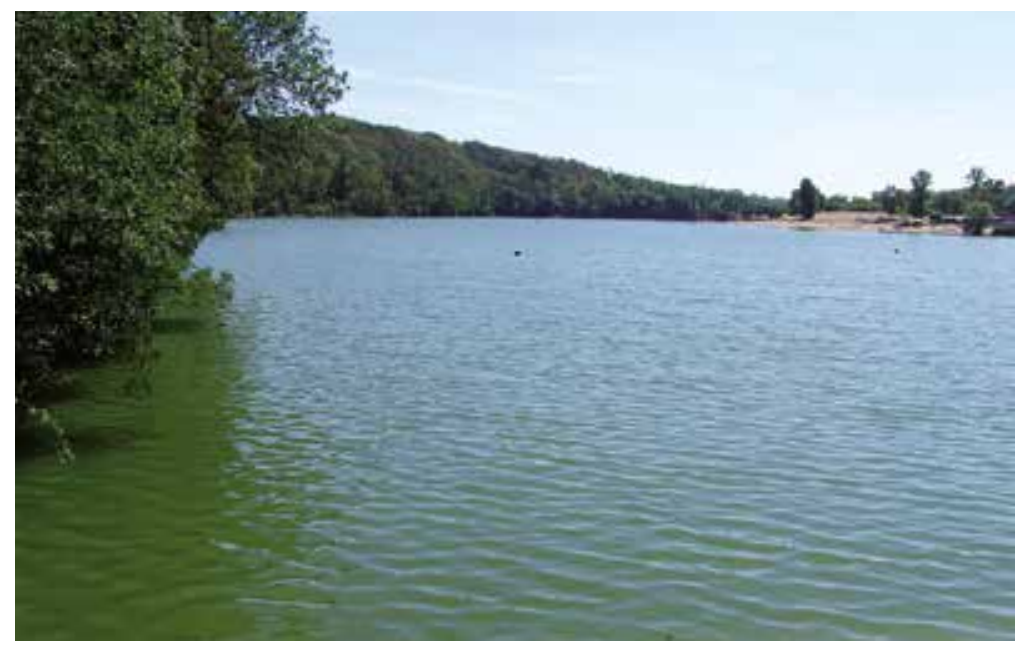

Obr. 25. Vodní květ sinic - přehradní nádrž Hostivař

Fig. 25. Cyanobacteria water bloom - Hostivař reservoir 


\section{ZÁVĚR}

Sledování př́toků do koupališt na jihovýchodě Prahy (rybník Šeberák, přehradní nádrž Hostivař) probíhalo v teplotně nadprůměrném a srážkově chudém roce 2018. Všechny prítoky (Vestecký a Kunratický potok, Botič) charakterizuje vysoký přísun živin (N, P), který svým projevem následně značně omezuje jejich rekreační využití. Podle údajů Hygienické stanice hl. m. Prahy [13] byla v sezonách 2017 a 2018 (především z důvodu nadměrného rozvoje sinic) voda obou koupališt’ charakterizována následovně:

A. rybník Šeberák (23 údajů, z toho):

— vhodná ke koupání: 0×,

— zhoršené smyslově postižitelné vlastnosti vody: $0 \mathrm{x}$,

— zhoršená jakost vody; nevhodná ke koupání pro vnímavé jedince: 4x,

- voda nevhodná pro koupání: 3x,

— zákaz koupání:16x.

B. přehradní nádrž Hostivař (26 údajů, z toho):

— vhodná ke koupání: 1X,

— zhoršené smyslově postižitelné vlastnosti vody: $2 x$,

— zhoršená jakost vody; nevhodná ke koupání pro vnímavé jedince: 15x,

— voda nevhodná pro koupání:7x

— zákaz koupání:1× (obr. 24 a 25).

Je zřejmé, že hlavním důvodem této situace je vysoký př́sun živin z přítoků s negativními důsledky pro obě nádrže. Bez opatření v jejich povodí lze jen stěží očekávat zlepšení podmínek pro rekreační využití obou lokalit.

\section{Poděkování}

Přispěvek vznikl za podpory projektu CZ.071.02/0.0/0.0/16_040/0000382: Rekreační potenciál vody v Praze - stav a výhledy; rešeného v rámci operačního programu Praha - pól růstu Il.

\section{Literatura}

[1] DESORTOVÁ, B., HAVEL, L. a ŠY̌ASTNÝ, J. Kvalita vody pražských potoků. Část 1: Motolský a Litovický potok. VTEI, roč. 61, č. 2, s. 20-29.

[2] Dostupné z: www. praha-priroda.cz/vodní-plochy-a-potoky.

[3] Mapa vodních toků a nádrží, lesů a chráněné přírody hl. m. Prahy, 2017

[4] MARŠÁLKOVÁ, E., PETŘíK, P. a MARŠÁLEK, B. Pošli to dál - aneb z čeho Průhonický park vyrábí biomasu sinic pro nádrž Hostivař? VTEl, roč. 61, č. 1, s. 15-20.

[5] ČSN EN ISO 5667-6 (75 7051). Kvalita vod - Odběr vzorků - Část 6: Návod pro odběr vzorků z řek a potoků. Praha: ÚNMZ, 2017.

[6] ČSN ISO 5667-4 (75 7051). Kvalita vod - Odběr vzorků - Část 4: Návod pro odběr vzorků z jezer a vodních nádrží. Praha: ÚNMZ, 2018.

[7] ČSN ISO 7150-1 (75 7451). Jakost vod - Stanovení amonných iontů - Část 1: Manuální spektrofotometrická metoda. Praha: ČNI, 2007.

[8] ČSN EN ISO 10304-1 (75 7391). Jakost vod - Stanovení rozpuštěných aniontů metodou kapalinové chromatografie iontů - Část 1: Stanovení bromidů, chloridů, fluoridů, dusičnanů, dusitanů, fosforečnanů a síranů. Praha: ÚNMZ, 2009.

[9] ČSN EN ISO 6878 (75 7465). Jakost vod - Stanovení fosforu - Spektrofotometrická metoda s molybdenanem amonným. Praha: ČNI, 2005

[10] ČSN ISO 10260 (75 7575). Jakost vod - měření biochemických ukazatelů - Spektrofotometrické stanovení koncentrace chlorofylu-a. Praha: ČNI, 1996.

[11] KOMÁRKOVÁ, J. Metodika odběru a zpracování vzorků fytoplanktonu stojatých vod. Praha: MŽP ČR, 2006

[12] PŘIKRYL, I. Metodika odběru a zpracování vzorků zooplanktonu stojatých vod. Praha: MŽP ČR, 2006.

[13] Dostupné z: www.hygpraha.cz

\section{Autoři}

RNDr. Ladislav Havel, CSc.

凶ladislav.havel@vuv.cz

RNDr. Blanka Desortová, CSc.

凶blanka.desortova@vuv.cz

Mgr. Jan Št'astný, Ph.D.

凶jan.stastny@vuv.cz

Výzkumný ústav vodohospodářský T. G. Masaryka, v. v. i.

Příspěvek prošel lektorským řízením.

WATER QUALITY OF THE

PRAGUE'S STREAMS. PART 2: TRIBU-

TARIES TO THE ŠEBERÁK POND AND TO THE HOSTIVAŘ RESERVOIR

HAVEL, L.; DESORTOVA, B.; STASTNY, J.

TGM Water Research Institute, p.r.i.

Keywords: Prague streams - water quality nutrients - phytoplankton - zooplankton

The possibility of a recreational use of some of the Prague reservoirs is limited mainly by the quality of the tributaries. The article follows the previous one and sums up the results of the water quality monitoring in selected profiles of the tributaries of the Šeberák pond (the Vestecký and the Kunratický streams) and of the Hostivař dam (the Botič and the Pitkovický streams) during 2018. The monitoring was focused on main nutrients (phosphorus, nitrogen) in the tributaries, chlorophyll-a concentrations and qualitative composition of phytoplankton and zooplankton in the reservoirs of the river basin. The amount of nutrients in the tributary limits primarily the recreational use of the Šeberák pond (mainly because of the Vestecký stream) - in years 2017 and 2018 the swimming in the pond was forbidden due to the excessive content of the blue-green algae in the course of the recreational season. The Botič stream brings less but also significant amount of nutrients into the Hostivař reservoir (worsened water quality for swimming was recorded during most of the 2017-2018 recreational season). The Milíčovský stream, which flows into the upper part of the Hostivař reservoir, is the main source of phytoplankton. 